\title{
Effects of fruit size and initial storage temperature on the heat of respiration of dacryodes edulis
}

\author{
O. J. ljabo, S. E. Obetta and E. O. Madugu \\ Department of Agricultural and Environmental Engineering, University of Agriculture, \\ Makurdi, Nigeria.
}

\begin{abstract}
Fresh fruits of Dacryodes edulis, also called African pears, in Markudi were characterized in terms of eight physical parameters namely length, mid-length diameter, fruit volume, weight and density, pulp thickness, pulp and seed weight. These were correlated with each other. Then a $3 \times 6$ two-factor experiment used to test for effects of initial storage temperature and fruit size on heat of respiration (HOR). HOR was determined by direct measurement of temperature difference in a closed chamber using a thermocouple. It was observed that the pears were of the small size class with thin pulp. Three parameters have high positive correlation with both pulp weight and thickness. Again it was found that size of pears has no significant effects on HOR at $\alpha=0.05$ while initial temperature has significant effect on HOR. The HOR of pears at 20,30 and $40^{\circ} \mathrm{C}$ were $0.0004150,0.001146$ and $0.002480 \mathrm{~W} / \mathrm{kg}$ respectively while the $\mathrm{Q}_{10}$ values in the temperature ranges of 20 to 30 and 30 to $40 \mathrm{C}$ were 2.76093 and 2.1641 respectively. Based on the values of HOR and $Q_{10}$ of African pears it is safe to store at $20^{\circ} \mathrm{C}$ whereas an increase in storage temperature of $10^{\circ} \mathrm{C}$ or $20^{\circ} \mathrm{C}$ could accelerate spoilage three or five times.
\end{abstract}

Key words: African Pears, Heat of Respiration, Correlation, Fruit, Size

\section{INTRODUCTION}

African pear, Dacryodes Spp, is an emerging economic fruit tree that can make a great contribution to poverty reduction in countries where it is grown. Although, the African pear is found throughout the tropics, it is grown mostly in the forest zone of Africa (Awono et. al., 2002; Anegbeh et al., 2006), especially Nigeria and Cameroon, accounting for 60 - $70 \%$ of world total output (Emebiri and Nwufo, 1990). Fruits of Dacryodes edulis or Dacryodes parvicarpa, are commonly known as African pear, African plum, native pear and butterfruit. The same African pear fruit is known as safou in Cameroun, 'Ube' in southeastern Nigeria and 'Eleme' in the southwestern Nigeria. Dacryodes species are very nutritious having controversial figures for the proximate analysis. For example, Leakey et. al. (2005) reported that the fruit of African pear has $48 \%$ oil, $25.9 \%$ protein, $17.9 \%$ fiber, $13.5 \%$ carbohydrate and vitamins with the oil being rich in amino acids (palmitic, oleic, stearic, linolenic and linoleic) and triglycerides (triacylglycols). In another contribution Onuegbu and Ihediohanma (2008) reported specifically that the African pear pulp has the following result of proximate analysis- protein, 11 to $19 \%$; oil, 18 to $38 \%$; carbohydrate, 1.36 to $3.8 \%$; acid, 0.92 to $1.7 \%$ and pulp moisture content of 37 to $53 \%$ wet basis. Whereas, Studman $(2006)$ gave the following percentages of $83.2,0.7,0.4,15.3,0.4$ for water, protein, fat, carbohydrate and minerals respectively with trace elements totaling 30.46 $\mathrm{mg} / 100 \mathrm{~g}$ for pears generally. African pear can either be eaten raw, boiled in salt water or roasted and eaten with maize (Ndindeng et al., 2008). Eradicating extreme poverty and hunger is the most important of the Millennium Development Goals (MDGs) that are currently the focus of the international development agenda (Schreckenberg, 2006) and it is expected that pears can greatly contribute to this goal.

There are high prospects for this crop. For example, a study in Cameroon indicated farm-level-value of the fruit production reaching \$US 161 annually per grower and the same study put its international trade in 1997 as being worth US $\$ 7.5$ million (Awono et al., 2002).

As promising as this crop is it has suffered neglect and tending towards being an endangered specie as suggested in the following scenario. Over two decades ago Emebiri and Nwufo (1990) observed that Nigeria and Cameroon accounts for $60-70 \%$ of world total output yet its production and trade figures 
have not been able to attain world recognition amongst other pears such as avocado pear, American pear, Australian pear and others as recorded in the FAO STAT (2011). While breeding research would help lift the global production figure of the crop, research in the fields of handling and storage are imperative to make the crop available to consumers beyond the day of harvest, the harvest season as well as the region of production. Personal observation of the investigators is that African pears sometimes cook and may even spoil in packages during transit and in storage in the hot tropical climate. It is suspected that a major contributor to such heat damage could be that it has a high heat of respiration. Wills et al., (1989) indicated that respiration rate of produce is an excellent indicator of metabolic activity of the tissue and thus is a useful guide to the potential storage life of the produce. The storage potential of African pear was investigated by Emebiri and Nwufo (1990) using four fruit types at ambient temperature of $28.5^{\circ} \mathrm{C}-30^{\circ} \mathrm{C}$, and found that those enclosed in either paper or polythene bags could be stored satisfactorily for $3-8$ days, after which they deteriorate rapidly. Emebiri and Nwufo (1990) also observed that storage life was increased at lower temperatures, but chilling injury occurred at about $5^{\circ} \mathrm{C}$. At $15^{\circ} \mathrm{C}$, fruits dipped in palm oil before being packaged were of better quality and retained their firmness longer than fruit dipped in a 500ppm benlate solution. Storage in moist saw dust, wood shavings and water were the least effective in extending shelf life. In another contribution, (Ndindeng et al., 2007) treated the fruits with SmartFresh $\AA$ (1-methylcyclopropene), and reported that there was significant increases in fruit shelf life from 3 days to 2 weeks at $25^{\circ} \mathrm{C}$, and with more than $95 \%$ of the fruits being of good quality. Thus it can be observed that no investigator has paid special attention to heat of respiration of the fruits. Pear fruits are generally known to be climacteric fruits (Wills et al., 1989; Studman, 2006) which suffer chilling injury at about $5^{\circ} \mathrm{C}$ (Emebiri and Nwufo, 1990). Thus, African pear is not only highly perishable but also delicate as the thermocomfort zone within which the shelf life is prolonged is short.

Heat of respiration could be obtained by first having a balanced chemical formula for the respiration reaction. As pear fruit contains both carbohydrate and fatty acids the respiration equations given by Wills et al., (1989) and Baerdemaeker et al., (2006) respectively, for the two nutrients, could be used in the process of physically measuring the amounts of the gases like $\mathrm{O}_{2}$ and $\mathrm{CO}_{2}$, ethylene and $\mathrm{H}_{2} \mathrm{O}$ involved during the respiration process followed by multiplying by the appropriate energy production factor. Besides, Baerdemaeker et al., (2006) indicated that as there is little cell development or growth in stored products, the respiration energy is mainly in the form of heat rather than adenosine triphosphate. A reason that can possibly explain why Alakali et al. (1995) used direct measurement of heat produced to determine the heat of respiration of yams.

There is controversy on sizes of African pear fruits relative to variety. Okafor (1983) identified two distinct varieties in Nigeria on the basis of their size and the relationship between the longitudinal and mid transverse circumferences. Likewise, (Schreckenberg, 2006) distinguished and identified two morphological types in markets in Cameroon. The two varieties are Dacryodes edulis and Dacryodes Parvicarpa . In contrast, (Leakey et al., 2005) reported that there is a continuous variation in fruit size and other fruit characteristics between samples found in Yaoundé Markets, also in Cameroun .

It is therefore, the objectives of this paper are to (i) characterize African pear fruits and (ii) determine the effects of selected initial storage temperatures and fruit size on the heat of respiration of African pear fruits using time-temperature-history in a closed container.

Theoretical Considerations: In an insulated enclosure, like an air-tight box, containing African pear fruits, a major source of heat is the heat of respiration. Since African pears is rich in carbohydrates, fatty acids and vitamins any or both of the chemical equations given by Wills et al., (1989) and Baerdemaeker et al., (2006) can represent the respiratory metabolism in the fruit. Whichever situation applies, two vital products, heat and water vapour are evolved. This heat of respiration so produced would be used to raise the temperature of both the fruits and air space within the box. As respiration proceeds, the heat of respiration would accumulate over time, $t$, as would be indicated by a temperature rise in the box above the initial storage temperature.. Because of the difference in temperature between the inside and outside of the box some of the heat of respiration will be lost through conduction to the storage environment. Assuming that the box is not opened during 
experimentation and there is no other source of heat, then heat of infiltration and miscellaneous heat can be negligible. Also, assuming that air at the various initial storage temperatures have relative humidity prevalent in the laboratory at the time of study which is predominantly approximately $80 \%$ in the months of July, August and September in Makurdi (ljabo, 2010), and that the water vapour from respiration increases this relative humidity in the storage chamber in the course of air-tight storage to saturation, then, the heat of respiration can be represented by equation 1 .

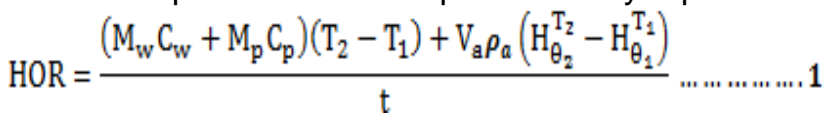

Theoretically, in a box containing graded fruits, volume occupied by the fruits in the box is the product of number of fruits and the mean volume of fruits in the particular class. Taking $\theta_{1}$ to be $80 \%$ and $\theta_{2}$ to be $100 \%$, equation 1 can be rewritten as equation 2.

HOR $={\frac{\left(M_{w} C_{w}+M_{p} C_{p}\right)\left(T_{2}-T_{1}\right)+\left(V_{b}-N_{f} V_{m f}\right) \rho_{a}\left(H_{100}^{T_{2}}-H_{80}^{T_{1}}\right)}{t}}_{t}^{\text {mm m m m. } 2}$

\section{MATERIALS AND METHODS Materials}

Storage box: The necessary storage environment was provided in form of a wooden storage box. These boxes were insulated to minimize heat exchange between the storage and the ambient environment. Foams of $8.44 \mathrm{~mm}$ thickness were used to line the inside of the $17.79 \mathrm{~mm}$ thick box thereby sealing both the cover of and the main boxes. The wooden material used for the box apart from serving as the framework and outer cover, also served as insulator. The inside walls of the box was further lined with Aluminum foil of $0.02 \mathrm{~mm}$ thick to preserve the insulating capacity for the wooden material, by preventing diffusion of water vapour through the walls of the box. If vapour is to be allowed to pass through the walls, it will condense and greatly hamper the insulating capacity of the other insulator.

The dimensions of the boxes and their components were being selected on the bases of the maximum diameter $(>40 \mathrm{~mm})$ and length $(>70 \mathrm{~mm})$ of the pear fruit to be experimented upon.

Pear Fruits: Fresh, intact fruits of Dacryodes edulis variety of African pear, harvested within 18 hours of supply were contract -purchased from dealers in Wadata Market Makurdi, Benue state of Nigeria in the months of August and September 2010. Each batch purchased was kept in the refrigerator for field heat to attain a stable temperature of $8^{\circ} \mathrm{C}$. First of all, 100 fruits were characterized in terms of eight parameters namely, length, mid-length diameter, volume, mass, density, pulp thickness, pulp weight and mass of seeds.

The experimental setup is as shown in figure 1. A DT - 830D digital multimeter with a range of 200 $1000 \mathrm{mv}$, direct current voltage (DCV) and 200 $750 \mathrm{mV}$, alternating current voltage (ACV) was used as the thermocouple readout to measure $\mathrm{mV}$ followed by appropriate conversion to degree Celsius. Three different air temperature environments were created by using an air conditioned room for $20^{\circ} \mathrm{C}$, while a general purpose incubator calibrated from $20^{\circ} \mathrm{C}$ to $100^{\circ} \mathrm{C}$ was set at $30^{\circ} \mathrm{C}$ and $40^{\circ} \mathrm{C}$ for the other two temperatures.

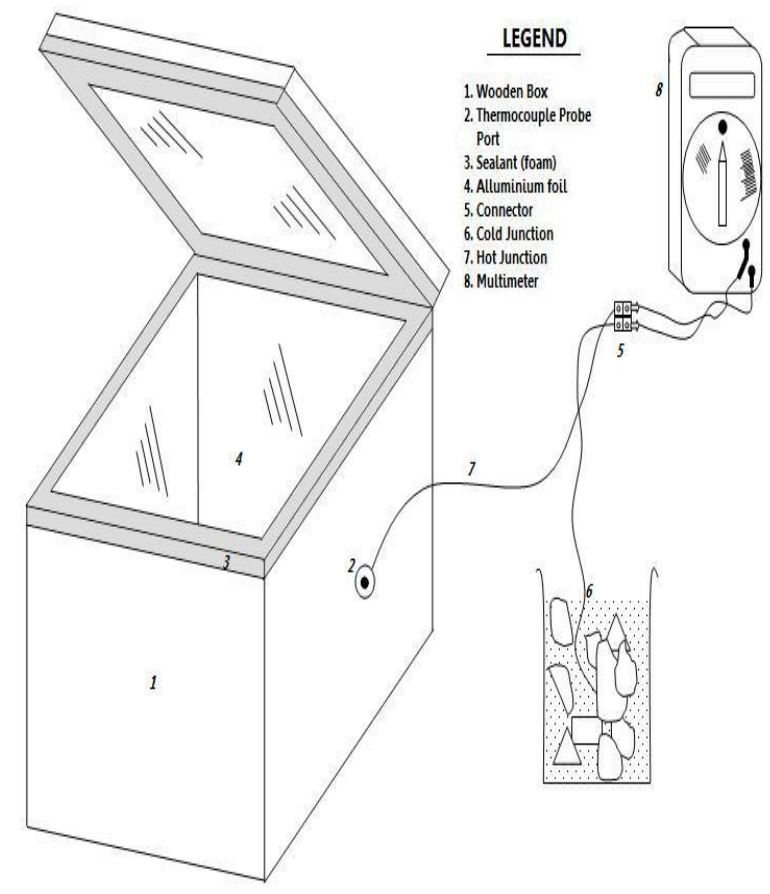

Fig. 1: Experimental set-up with an empty box and an Inserted thermocouple

Experimental Design and Methods: $A 3 \times 6$ two factor experimental design with three replications was used to determine the effects of initial storage temperature and fruit size on the heat of respiration of African pears. The boxes of pears were stored at 
three different initial temperatures of $20^{\circ} \mathrm{C}, 30^{\circ} \mathrm{C}$ and $40^{\circ} \mathrm{C}$ which formed the first factor. The second factor was the size class of the fruits at six levels. The samples were packaged according to the size class into the various marked pre-weighed boxes. The size class was based on the fruit character with the highest range. The boxes were then re-weighed. Each of the boxes carried a thermocouple (Type-T junction) inserted through tiny openings of about $5 \mathrm{~mm}$ in diameter into the boxes. These thermocouples were marked, corresponding to the marked boxes. The thermocouple was calibrated by heating water gradually to the boiling point.

\section{RESULTS AND DISCUSSIONS}

Characterization of fruits: The characteristics of the African pears used in this study are given in terms of descriptive statistics shown in Table 1 with density having the widest range followed by length of the fruit. However, since density is a derived parameter length of fruit, which is a single factor, was preferentially used to classify the fruits into the six classes of 21-30, 31-40, 41-50, 51-60, 60-70 and >70 $\mathrm{mm}$ used for testing the effect of fruit size on the heat of respiration of African pears. The other mean parameters of the fruit are $52.21 \pm 1.58 \mathrm{~mm}, 26.91 \pm$ $0.89 \mathrm{~mm}, 31.16 \pm 1.28 \mathrm{~g}, 4.97 \pm 0.18 \mathrm{~mm}, 20.52 \pm$ $1.16 \mathrm{~g}, 10.62 \pm 0.44 \mathrm{~g}, 3.65 \pm 0.37 \mathrm{~cm}^{3}$, and $1,078 \pm$ $22.2 \mathrm{~kg} / \mathrm{m}^{3}$ for fruit length, mid-length diameter, weight, pulp thickness, pulp weight, seed weight, volume of fruit and fruit density respectively. Matching the mean parameters in this study, the mean mass is $31.16 \pm 12.75 \mathrm{~g}$ which is less than the $50 \mathrm{~g}$ given by Leaky et al. (2005) as the upper limit for small fruits which is also the upper limit for Ndindeng et. al's (2008) class of very small fruits. Similarly, the mean pulp thickness of $4.97 \pm 1.82 \mathrm{~mm}$ is less than $6 \mathrm{~mm}$ suggested by Leakey et al. (2005) as the threshold value for the class of pears with thin pulp. So the African pears in Makurdi can be described as small pears with thin pulp.

Table 1: Descriptive statistics of eight parameters of African pear fruit

\begin{tabular}{|c|c|c|c|c|c|c|c|c|}
\hline & \multicolumn{8}{|c|}{ FRUIT PARAMETER } \\
\hline STATISTIC & $a(m m)$ & $b(\mathrm{~mm})$ & $\begin{array}{c}\text { Weight, } \\
g\end{array}$ & $\begin{array}{c}\text { Pulp } \\
\text { thickness } \\
(\mathrm{mm})\end{array}$ & $\begin{array}{c}\text { Pulp } \\
\text { weight } \\
\text { (g) }\end{array}$ & $\begin{array}{c}\text { Seed } \\
\text { weight } \\
\text { (g) }\end{array}$ & $\begin{array}{c}\text { Vol. of } \\
\text { fruit }\left(\mathrm{cm}^{3}\right)\end{array}$ & $\begin{array}{c}\text { Density, } \\
\mathrm{kg} / \mathrm{m}^{3}\end{array}$ \\
\hline Mean & 52.21 & 26.91 & 31.16 & 4.97 & 20.52 & 10.62 & 3.65 & $1,078.10$ \\
\hline Standard Error & 1.58 & 0.89 & 1.28 & 0.18 & 1.16 & 0.44 & 0.37 & 22.21 \\
\hline Median & 52.97 & 26.07 & 30.11 & 4.65 & 18.30 & 9.73 & 3.06 & $1,025.00$ \\
\hline Mode & 79.67 & 25.01 & 25.33 & 3.01 & 18.30 & 14.50 & 1.10 & 950.00 \\
\hline Standard Deviation & 15.83 & 8.90 & 12.75 & 1.82 & 11.59 & 4.42 & 3.65 & 222.06 \\
\hline Sample Variance & 250.59 & 79.28 & 162.67 & 3.32 & 134.24 & 19.53 & 13.36 & $49,310.49$ \\
\hline Kurtosis & -0.74 & -0.77 & -0.33 & -0.61 & -0.21 & 1.04 & 52.40 & 6.17 \\
\hline Skewness & 0.07 & 0.24 & 0.41 & 0.47 & 0.77 & 1.02 & 6.36 & 2.02 \\
\hline Range & 65.51 & 35.48 & 53.41 & 7.45 & 48.38 & 23.32 & 33.75 & $1,440.00$ \\
\hline Minimum & 20.52 & 11.34 & 9.89 & 1.45 & 4.32 & 3.08 & 0.85 & 720.00 \\
\hline Maximum & 86.03 & 46.82 & 63.30 & 8.90 & 52.70 & 26.40 & 34.60 & $2,160.00$ \\
\hline Sum & $5,220.55$ & $2,691.16$ & $3,116.45$ & 496.70 & $2,052.01$ & $1,061.76$ & 365.34 & $107,810.00$ \\
\hline Count & 100 & 100 & 100 & 100 & 100 & 100 & 100 & 100 \\
\hline $\begin{array}{l}\text { Confidence Level } \\
(95.0 \%)\end{array}$ & 3.14 & 1.77 & 2.53 & 0.36 & 2.30 & 0.88 & 0.73 & 44.06 \\
\hline
\end{tabular}

correlation of these parameters measured directly

Table 2 gives the correlation table for the eight parameters investigated. Some of these parameters like the length, mid-length diameter and mass of individual fruits are all measured directly and nondestructively unlike pulp thickness, density, volume and seed weight which are either indirect, derived or destructive measurements. Therefore, the high and non-destructively with the less economic determinations means that the simpler ones can be used to predict the more difficult parameters.

Interestingly three easy-to-measure parameters of length, mid-length diameter and fruit mass all have 
high positive correlation with both pulp thickness and pulp mass. An example of the application is the use of fruit mass to determine the pulp mass. The pulp is
$66 \%$ of the fruit by mass. This percentage can be used in an oil production process line to predict the amount of pulp available for oil extraction

Table 2: Correlation Analysis of Properties of African Pear Using 100 Fruits

\begin{tabular}{|l|r|r|r|r|r|r|r|l|}
\hline PARAMETER & $a(\mathrm{~mm})$ & $b(\mathrm{~mm})$ & $\begin{array}{c}\text { Weight, } \\
\mathrm{g}\end{array}$ & $\begin{array}{c}\text { Pulp } \\
\text { thickness } \\
(\mathrm{mm})\end{array}$ & $\begin{array}{c}\text { Pulp } \\
\text { weight } \\
(\mathrm{g})\end{array}$ & $\begin{array}{c}\text { Seed } \\
\text { weight } \\
(\mathrm{g})\end{array}$ & $\begin{array}{c}\text { Vol. of } \\
\text { fruit } \\
(\mathrm{cm} 3)\end{array}$ & $\begin{array}{c}\text { Density } \\
(\mathrm{g} / \mathrm{cm})\end{array}$ \\
\hline $\mathrm{a}(\mathrm{mm})$ & 1 & & & & & & & \\
\hline $\mathrm{b}(\mathrm{mm})$ & 0.9462 & 1 & & & & & & \\
\hline Weight, g & 0.9444 & 0.9647 & 1 & & & & & \\
\hline $\begin{array}{l}\text { Pulp-thickness } \\
\text { (mm) }\end{array}$ & 0.9368 & 0.8834 & 0.9069 & 1 & & & & \\
\hline Pulp weight (g) & 0.9007 & 0.8872 & 0.9380 & 0.9183 & 1 & & & \\
\hline Seed weight (g) & 0.3611 & 0.4555 & 0.4246 & 0.2088 & 0.0845 & 1 & & \\
\hline Vol. of fruit (cm3) & 0.3310 & 0.3107 & 0.3333 & 0.2940 & 0.2898 & 0.2014 & & 1 \\
\hline Density (g/cm3) & -0.5055 & -0.4737 & -0.4512 & -0.5170 & -0.4872 & -0.0260 & -0.2643 & \\
\hline
\end{tabular}

Calibration of Thermocouple: The calibration curve of the type T- junction (copper - Constantine) is a straight line with the slope of 22.35, y-intercept of 13.75 and an $R^{2}$ value of 0.9151 as shown in Figure 2 which was used to convert the thermocouple readings to temperature, ${ }^{\circ} \mathrm{C}$.

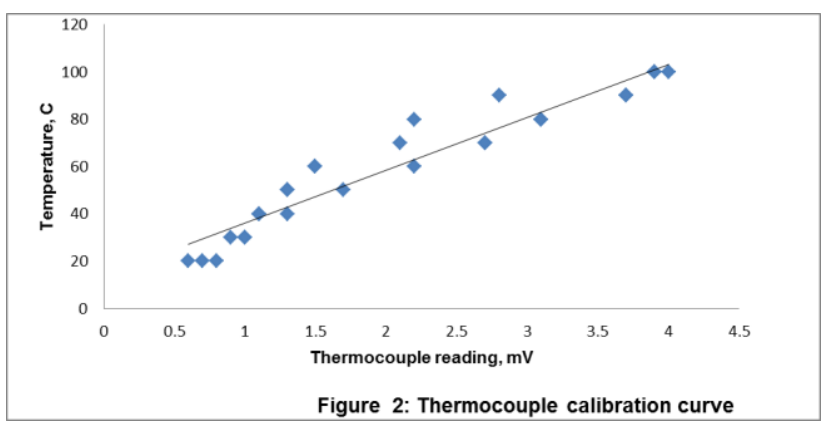

Heat of respiration: The relevant temperature readings and the corresponding enthalpies together with the parameters in the descriptive statistics plus specific heat of pears as given by Mosennin (1980) were substituted into equation 2 to get the heat of respiration at various treatments. The ANOVA for testing of the significant effects of fruit size and initial storage temperature as indicated in Table 3 shows that only initial storage temperature has significant effect on HOR of African pears at $\alpha=0.05$ while both fruit size and interaction have no significant effect. Since fruit size of African pears were fund to be insignificant the heat of respiration at each of the three initial storage temperatures were lumped together for separation of means using t-Test: TwoSample Assuming Unequal Variances of Microsoft Excel. The HORs were 0.000415042, 0.0011459 and $0.002479806 \mathrm{w} / \mathrm{kg}$ at $20^{\circ} \mathrm{C}, 30^{\circ} \mathrm{C}$ and $40^{\circ} \mathrm{C}$ respectively. Using the conversion factor given by Baerdemaeker et al. (2006) to convert the HOR given generally for pears by Wills et al. (1989) as $0.208055556 \mathrm{w} / \mathrm{kg}\left(70 \mathrm{mg}\right.$ of $\left.\mathrm{CO}_{2} \mathrm{~kg}^{-1} \mathrm{~h}^{-1}\right)$ to compare with the values specifically obtained for African pears in this study there is a difference in the order of thousands $\left(10^{3}\right)$. 
Am. J. Sci. Ind. Res., 2012, 3(3): 150-156

Table 3: ANOVA of heat of respiration of African pears of different fruit sizes and initial storage temperatures

\begin{tabular}{|l|r|r|r|r|r|r|c|}
\hline Source of Variation & \multicolumn{1}{c|}{$S S$} & \multicolumn{1}{c|}{$d f$} & \multicolumn{1}{c|}{$M S$} & \multicolumn{1}{c|}{$F$} & \multicolumn{1}{c|}{-value } & \multicolumn{1}{c|}{ crit } & Remarks \\
\hline Temperature & $3.9 \mathrm{E}-05$ & 2 & $1.95 \mathrm{E}-05$ & 38.48337 & $1.15 \mathrm{E}-09$ & 3.259446 & ${ }^{*}$ \\
\hline Size & $1.27 \mathrm{E}-06$ & 5 & $2.54 \mathrm{E}-07$ & 0.501832 & 0.7728 & 2.477169 & $\mathrm{~ns}$ \\
\hline Interaction & $8.48 \mathrm{E}-07$ & 10 & $8.48 \mathrm{E}-08$ & 0.167399 & 0.997584 & 2.106054 & $\mathrm{~ns}$ \\
\hline Within & $1.82 \mathrm{E}-05$ & 36 & $5.07 \mathrm{E}-07$ & & & & \\
\hline Total & $5.94 \mathrm{E}-05$ & 53 & & & & & \\
\hline
\end{tabular}

*Significant at $=0.05$

ns Not significant

Furthermore, the $Q_{10}$ values were estimated for the temperature ranges of $20^{\circ} \mathrm{C}$ to $30^{\circ} \mathrm{C}$ and $30^{\circ} \mathrm{C}$ to $40^{\circ} \mathrm{C}$ to be 2.76093 and 2.1641 respectively. The $Q_{10}$ for the temperature range of $20^{\circ} \mathrm{C}$ to $30^{\circ} \mathrm{C}$ obtained in this study for African pears is slightly higher than the $Q_{10}$ value for respiration for many products which Baerdemaeker et al. (2006) put at between 2.0 and 2.5 in the temperature range of $2{ }^{\circ} \mathrm{C}$ and $25^{\circ} \mathrm{C}$. This might mean that the mass loss and heat produced by African pears will increase more than that of many other biological materials either when it is at a temperature higher than $20^{\circ} \mathrm{C}$ or there is a fluctuation in temperature in the course of transportation or storage leading to attainment of temperatures higher than $20^{\circ} \mathrm{C}$ which may be the reason for self-cooking in a package of African pears during handling and storage in the tropics like Makurdi, the area of study.

\section{CONCLUSION}

Length of fruit is the best criterion for classifying the fruits of African pears. The mean parameters of the fruit are $52.21 \pm 1.58 \mathrm{~mm}, 26.91 \pm 0.89 \mathrm{~mm}, 31.16 \pm$ $1.28 \mathrm{~g}, 4.97 \pm 0.18 \mathrm{~mm}, 20.52 \pm 1.16 \mathrm{~g}, 10.62 \pm 0.44$ $\mathrm{g}, 3.65 \pm 0.37 \mathrm{~cm}^{3}$, and $1,078 \pm 22.2 \mathrm{~kg} / \mathrm{m}^{3}$ for fruit length, mid-length diameter, weight, pulp thickness, pulp weight, seed weight, volume of fruit and fruit density respectively. African pears in Makurdi can be described as small pears with thin pulp. Three easyto-measure parameters of length, mid-length diameter and fruit mass all have high positive correlation with both pulp thickness and pulp mass and can be used to predict them. Based on the values of $H O R$ and $Q_{10}$ of African pears in the hot tropics it is safe to store African pear at $20^{\circ} \mathrm{C}$ to prolong the shelf-life whereas an increase in storage temperature of $10^{\circ} \mathrm{C}$ or $20^{\circ} \mathrm{C}$ could accelerate spoilage three or five times.
Definition of Symbols $\mathrm{C}_{\mathrm{p}}=$ Specific heat of pears, $\mathrm{Jkg}^{-1} \mathrm{C}^{-1}$ $\mathrm{Jkg}^{-1} \circ \mathrm{C}^{-1}$

$\mathrm{Cw}=$ Specific heat of wood used for the box, $\mathrm{H}_{\theta}^{\mathrm{T}}=$ Enthalpy at temperature $\mathrm{T}$ and

Relative humidity $\theta, \mathrm{kJ} / \mathrm{kg}$ dry air HOR = Heat of respiration, $w / k g$

$\mathrm{M}_{\mathrm{p}}=$ Mass of pears, $\mathrm{kg}$

Mw $=$ Mass of wooden box, $\mathrm{kg}$

$\mathrm{N}_{\mathrm{f}}=$ Number fruits in a box

$\mathrm{T}=$ Temperature,${ }^{\circ} \mathrm{C}$

$\mathrm{t}=$ Time it takes the temperature to rise from

$T_{1}$ to $T_{2}$, seconds

$\mathrm{V}_{\mathrm{a}}=$ Volume of air in the enclosure, $\mathrm{m}^{3}(=$

volume of box - volume of fruit in the box)

$\mathrm{Vb}=$ Volume of box, $\mathrm{m}^{3}$

$\mathrm{Vmf}=$ mean volume of a fruit in the class, $\mathrm{m}^{3}$

$\rho_{\mathrm{a}}=$ Density of air in the enclosure, $\mathrm{kg} / \mathrm{m}^{3}$

Subscript "1" initial condition "2" final condition

\section{REFERENCES}

Alakali, J. S.; Obetta S. E. and O. J. ljabo. 1995. Heat of respiration of yam tubers and its effect on heat load. African Journal of roots and tubers, 1(1): $31-35$.

Anegbeh, P. O.; V. Ukafor, C. Usoro, Z. Tchoundjeu,R. R. B. Leakey, and K. Schreckenberg. 2005.

Domestication of Dacryodes edulis: 1. Phenotypic variation of fruit traits from 100 trees in southeast Nigeria. New Forest (2005) 29:149-160

Awono, A; O. Ndoye, K. Schreckenberg, H. Tabuna and F. Isseri. 2002. Production and Marketing of Safou (Dacryodes Edulis) in Cameroon and Internationally: Market Development Issues. Forests, Trees and Livelihoods Vol. 12 pp125 - 147 
Baerdemaeker,J. De; N. Scheerlinck, P. Jancs'ok, and P. Verboven. 2006. Root Crops. Chapter 2 in Volume IV: Agro-processing Engineering in CIGR handbook of Agricultural Engineering. Ed CIGR -The International Commission of Agricultural Engineering. Pp 69-80

Emebiri, L. C., Nwufo, M.I (1990) Effect of fruit types and storage treatments on shelf-life of Dacryodes edulis. The biodegradation 26(1): $43-50$.

FAOSTAT. Fruits and vegetable production statistics. 2011. FAO Statistics Division 2011. Accessed on 10 February 2011

ljabo, O. J. 2010. Studies in desiccant properties of rice husk ash (RHA). Doctoral Thesis in Processing and Storage Engineering, Department of Agricultural and Environmental Engineering, University of Agriculture, Makurdi. Pp 239.

Leakey, R.R.B, Tchoundjeu, Z., Schreckenberg, K., Schacleton, S.E and Shackleton, C.M. (2005). Agroforestry tree products (AFTPS): Targeting poverty and enhanced livelihoods. International Journal of Agricultural sustainability 3(1): $1-23$.

Mohsenin, N. N. 1980. Thermal properties of foods and agricultural materials. Gordon and Breach Science Publishers. London. Pp 407.

Ndindeng. S.A., Bella-Manga, Kengue, J., Talle and Lewis, D.L. 2008. Quality standards for Dacryodes edulis (safou). Research Report No. 5. International Centre for Underutilised Crops, Colombo, Sri Lanka. 26 pp. Nzembe.pdf Accessed on 28 August 2010.
Ndindeng, S.A., Kengue, J., Mbacham, W.F., Titanji V.P.K. and Bella-Manga. 2007. Effects of 1methylcyclopropene treatment on the shelf life and quality of safou (Dacryodes edulis. Forest, Trees and Livelihoods, 17(1): 75-89.

Okafor, J.C. (1983) Varietal delimitation in Dacryodes edulis International tree crops Journal Vol. 2 pp: 225 265.

Onuegbu, N. C.; Ihediohanma, N. C. 2008. Some Proximate Analysis of African Pear (Dacryodes Edulis). J. Appl. Sci. Environ. Manage. March, 2008 Vol. 12(1) 83 - 85. Full-text Available Online at www.bioline.org.br/ja Accessed on August 28, 2010

Schreckenberg, K,; A. Awono, A.; Degrande, C. Mbosso,; O. Ndoye,; and Z. Tchoundjeu. 2006. Domesticating indigenous fruit trees as a contribution to poverty reduction. Forests, Trees and Livelihoods, 2006, Vol. 16, pp. 35-51

Studman, C. J. 2006. Fruit and vegetables. Chapter 3 in Volume IV: Agro-processing Engineering in CIGR handbook of Agricultural Engineering. Ed CIGR -The International Commission of Agricultural Engineering. P 278.

Wills, R.B.H.; W.B. McGlasson, D. Graham, T. H. Lee and E. G. Hall. 1989. Postharvest: An introduction to the physiology and handling of fruit and vegetables. 3ed. BSP Professional Books, London. P24. 